\title{
SEABED TOPOGRAPHY MAPPING IN SANGIHE TALAUD WATERS USING MULTIBEAM ECHOSOUNDER
}

\section{PEMETAAN TOPOGRAFI DASAR LAUT DI PERAIRAN SANGIHE TALAUD MENGGUNAKAN MULTIBEAM ECHOSOUNDER}

\author{
Dwi Haryanto $^{1}$, Muhamad Irfan ${ }^{1}$, Taufan Wiguna ${ }^{1}$, and \\ Hendra Kurnia Febriawan ${ }^{1}$ \\ ${ }^{1}$ Laboratory for Marine Survey Technology, Agency for Assessment and Application of \\ Technology (BBPT), Jl. MH. Thamrin 8, Jakarta, Indonesia \\ *E-mail: dwi.haryanto@bppt.go.id
}

\begin{abstract}
The application of multibeam echosounder for seabed topographic mapping is commonly used recently. Multibeam echosounder is an efficient tool to get a wide seabed coverage for each measurement ping, since it can produce high-resolution seabed topography maps. These maps can be used for further investigation or exploration, such as geomorphology and marine habitats studies. RV Baruna Jaya IV, which is operated by Laboratory for Marine Survey Technology BPPT, had been equipped with a Germany technology, a hull mounted multibeam echosounder system of Seabeam 1050D. The Seabeam 1050D allows to cover the seabed using 126 beams simultaneously in both sides (port and starboard). RV Baruna Jaya IV and RV Okeanos Explorer of NOAA conducted a joint Indonesia - U.S. Expedition to Sangihe Talaud waters (INDEX SATAL) in the northern area of the North Sulawesi Province during July - August, 2010. While seabed topography which less than $2000 \mathrm{~m}$ was covered by Seabeam 1050D system, the deeper area between $2000 \mathrm{~m}$ and $6000 \mathrm{~m}$ was covered by Simrad EM-302 system from RV Okeanos Explorer. The result shows that seabed Sangihe Talaud waters has a vary seabed topography. In addition, the resulted map showed a $1600 \mathrm{~m}$ height of seamount, risen up from the depth of $2300 \mathrm{~m}$ to $710 \mathrm{~m}$ below the sea surface. Others geological features can be identified according to high resolution bathymetry map resulted from this study.
\end{abstract}

Keywords: multibeam echosounder, seabed topography, seamount, Sangihe Talaud

\section{ABSTRAK}

[Pemetaan Topografi Dasar Laut di Perairan Sangihe Talaud Menggunakan Multibeam Echosounder] Penggunaan multibeam echosounder untuk pemetaan topografi dasar laut telah umum digunakan saat ini. Multibeam echosounder adalah alat yang efisien untuk mendapatkan cakupan dasar laut yang luas, sehingga dapat menghasilkan peta topografi dasar laut resolusi tinggi. Peta-peta ini dapat digunakan untuk penyelidikan atau eksplorasi lebih lanjut, misalnya studi geomorfologi dan habitat laut. KR Baruna Jaya IV yang dioperasikan oleh Balai Teknologi Survei Kelautan - BPPT telah dilengkapi dengan multibeam echoounder teknologi Jerman, yaitu sistem Seabeam 1050D yang dipasang di lambung kapal. Seabeam 1050D memungkinkan untuk merekam topografi dasar laut menggunakan 126 beam secara bersamaan melintang dari kiri ke kanan kapal. KR Baruna Jaya IV dan KR Okeanos Explorer dari NOAA telah melakukan Ekspedisi gabungan Indonesia - AS keperairan Sangihe Talaud (INDEX SATAL) di wilayah utara Provinsi Sulawesi Utara selama bulan Juli - Agustus 2010. Topografi dasar laut dengan kedalaman kurang dari 2000m direkam datanya oleh sistem Seabeam 1050D, sedangkan area yang lebih dalam antara 2000m dan 6000 m direkam datanya oleh sistem Simrad EM-302 dari KR Okeanos Explorer. Hasil penelitian menunjukkan bahwa dasar laut di perairan Sangihe Talaud memiliki variasi topografi dasar laut. Selain itu, peta yang dihasilkan menunjukkan adanya gunung laut dengan ketinggian $1600 \mathrm{~m}$, naik dari kedalaman $2300 \mathrm{~m}$ ke $710 \mathrm{~m}$ di bawah permukaan air laut, serta fitur geologi lainnya dapat diidentifikasi dari peta batimetri resolusi tinggi.

Kata Kunci: multibeam echosounder, topografi dasar laut, gunung laut, Sangihe Talaud 


\section{INTRODUCTION}

Since the World Ocean Conference (WOC) in 2009, North Sulawesi Province of Indonesia is becoming more popular due to its beauty of nature. The hilly land topography and mountainous area reflect the variety of land use. To the north of Sulawesi, several islands are spreading irregularly with their various sizes. Several main islands in those areas, which are not widely known by the Indonesian people, are Sangihe and Talaud Islands. Sulawesi Sea and Pacific Ocean surround those islands in the west and east directions, respectively. The Philippine main land is located just across the sea less than 200nm to the north. Various and steep topographies down to 5000s meters depth describes the ocean bottom in the area.

Sangihe Islands consist of several small islands which distributed in the northsouth direction. Siau Island, which is one of the island, is located 40nm to the south of main Sangihe Island. A $1827 \mathrm{~m}$ volcano raises up as a geographic landmark of this island. Very steep and deep coastal waters surround the island. This volcano is one of the active volcano within the Sangir-Talaud Islands.

A joint Indonesia - U.S. Expedition to Sangihe Talaud waters (INDEX SATAL) in the north area of the North Sulawesi Province was conducted by the RV Okeanos Explorer of NOAA and the RV Baruna Jaya IV of Indonesia during July - August, 2010 (Wirasantosa et al., 2010). Seabed topography was one of the multi aspects-discoveries as the purpose of this Expedition. Considering the advantage of both ship capabilities, RV Okeanos Explorer covered area between 2000 meters and 6000 meters depth, while RV Baruna Jaya IV covered area of less than 2000 meters depth (Figure 1). The survey area of Exploration Sangihe Talaud (INDEX SATAL) 2010 covering territorial water of Archipelago of Sangihe Talaud in North Sulawesi, started from north of Manado until the border of Indonesia - Philippine, as shows by red line area. In this study, the complexity of seabed topography in Sangihe Talaud waters will be verified using multibeam echosounder Seabeam 1050D system.

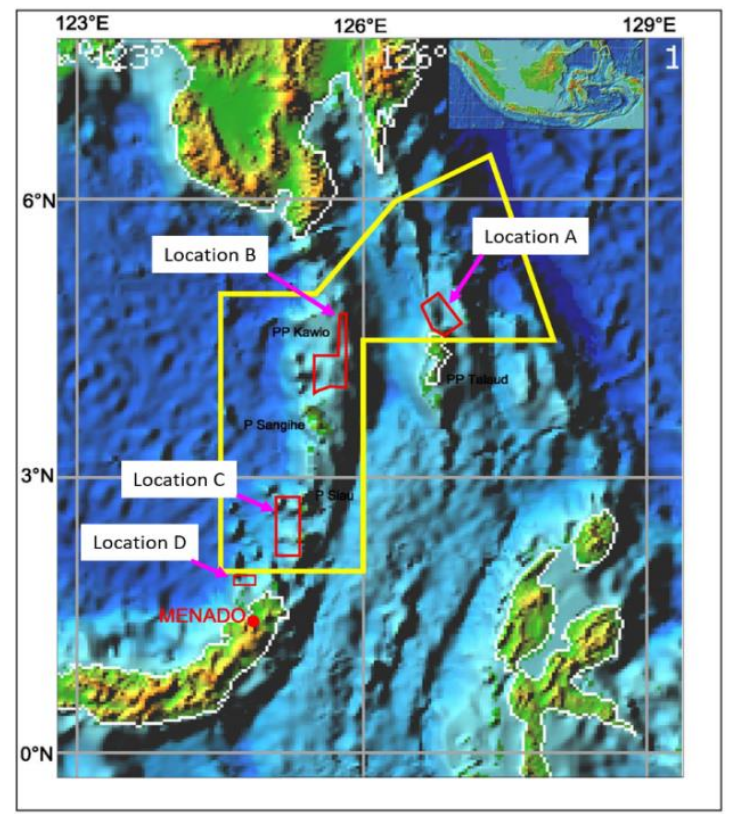

Figure 1. Study area of RV Baruna Jaya IV; shows by red line area. There are four locations: north of Talaud Island (Location A), north of Sangihe Island (Location B), west of Siau Island (Location C), and north of Nain Island (Location D). 


\section{MATERIALS AND METHODS}

\subsection{MBES System Preparation}

MBES system that used in this study was Seabeam 1050D by ELAC NautikGermany. Seabeam 1050D has dual-frequencies, $50 \mathrm{kHz}$ and $180 \mathrm{kHz}$. The $50 \mathrm{kHz}$ frequency can measure seabed topography until $3000 \mathrm{~m}$ water depth. These are 126 umber of beams with the swath width is $153^{\circ}$. This study only describes the result using transducer with $50 \mathrm{kHz}$ frequency. The Hydrostar software was used for multibeam data acquisition and display the seabed topography and depth profile in real-time, so it can be directly monitored during multibeam data acquisition. Multibeam data processing can be performed onboard processing so the results can be seen immediately, after finished the survey. The maximum coverage area and water depth from Seabeam 1050D can be seen in the Figure $2 \mathrm{a}$.

The Seabeam1050D consist of transducer (projector and receiver) with a frequency $50 \mathrm{kHz}$, sonar processing unit SEE-30, surface sound velocity real time (SV real time), sound velocity profile, and integrated inertial navigation system. The integrated inertial navigation system usedF180 Coda Octopus that integrates the data from GNSS Receiver, GPS Gyro, and Inertial Motion Unit. The configuration of Seabeam1050D is shown in Figure 2b.

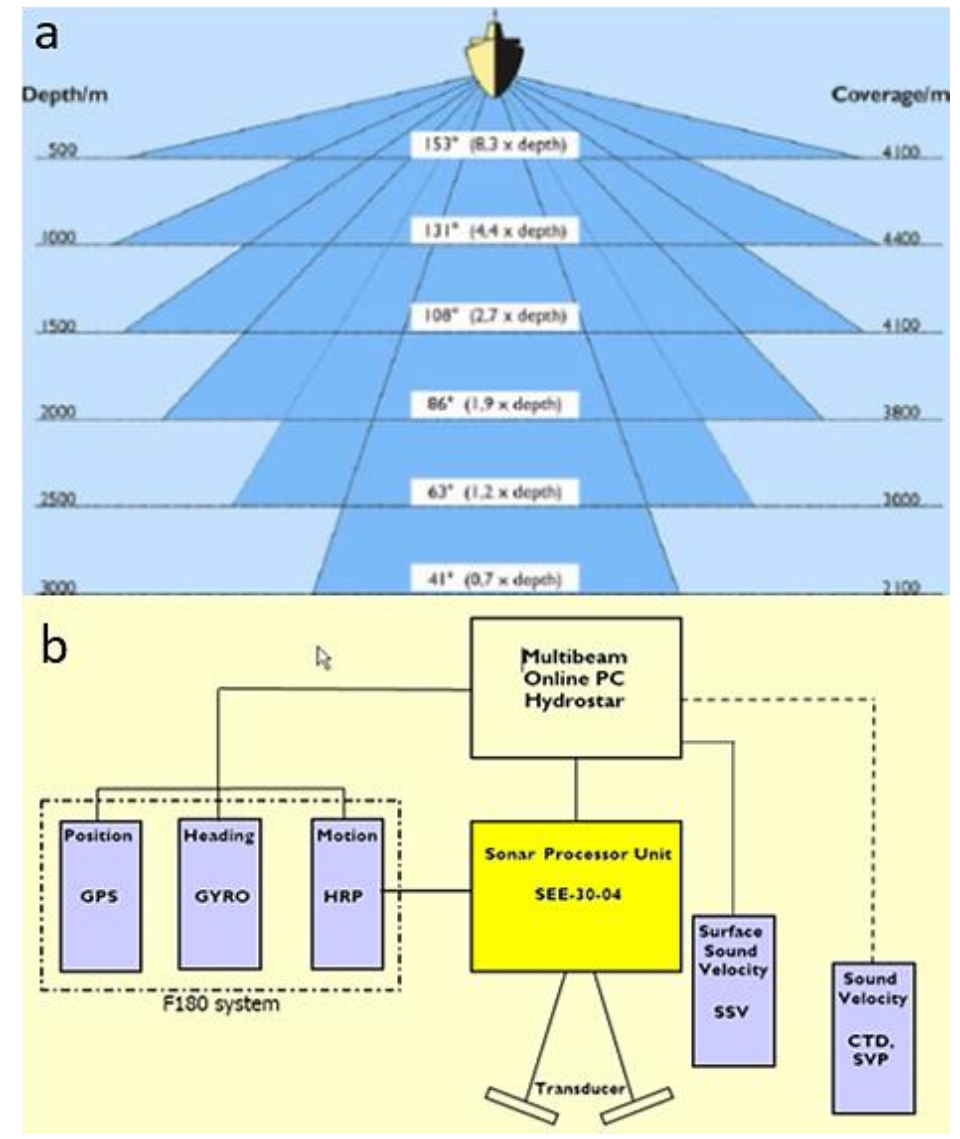

Figure 2. (a) Coverage area according water depth of Seabeam 1050D, (b)

Configuration of Seambeam 1050D in RV Baruna Jaya IV

Modified from L-3 Communications ELAC Nautik GmbH (2013). 
Vessel Reference Frame (VRF) is defined with Reference Point (RP) is located in the intersection between waterline and transducer head (Figure 3). Based on the Elac sign convention, $\mathrm{Y}$-axis is always positive directed from the Reference Point to the Bow. X-axis is always positive directed from the Reference Point to the left, looking at bow direction. Z-axis is always positive directed from the Reference Point to downwards (Figure 3a and Figure 3b). The following sensors (antenna of the DGPS, IMU, and center of active surface of each transducer (Port and Starboard) need to be referenced to the Reference Point in 3D direction. This sensors arrangement is commonly called with sensors offset. Sensor offset were measured using dimensional control survey method while the vessel was on a floating dry dock. The sensors offset diagram is illustrated in Figure $3 \mathrm{c}$ and Table 1.

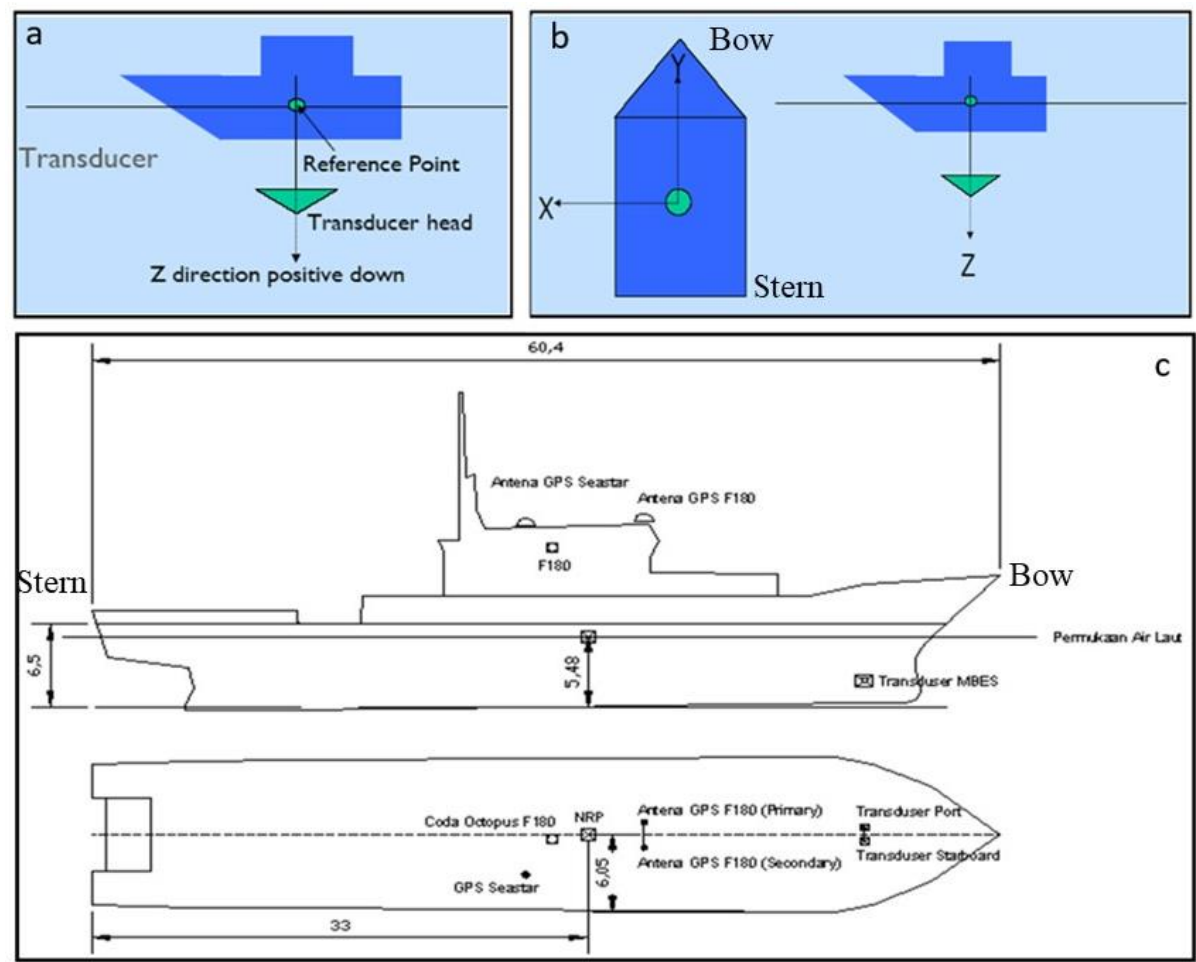

Figure 3. (a) Position of Reference Point (RP), (b) Vessel reference frame in Elac sign Convention, (c) Sensor offset at RV Baruna Jaya IV.

Table 1. Offset Sensors.

\begin{tabular}{llcccl}
\hline No & \multicolumn{1}{c}{ Sensor } & \multicolumn{3}{c}{ Offset from RP } & \multicolumn{1}{c}{ Comment } \\
\cline { 3 - 6 } & & $\mathbf{X ~ ( m )}$ & $\mathbf{Y}(\mathbf{m})$ & $\mathbf{Z}(\mathbf{m})$ & \\
\hline 1 & Reference Point (RP) & 0 & 0 & 0 & The intersection between \\
& & & & & Waterline and Transducer Pole \\
2 & Transducer Port & 0.53 & 0 & 3.4 & Mounted angle 38.05 \\
3 & Transducer Starboard & -0.53 & 0 & 3.4 & Mounted angle $38.05^{\circ}$ \\
4 & DGPS (F180) & 0.96 & -14.65 & -12.45 & Antenna DGPS \\
\hline
\end{tabular}

The calibration (patch test) needs to be performed before the survey. The MBES calibration is used to determine the system components such as roll, pitch, yaw offsets and navigation string latency. The Seabeam 1050D calibration has been done and the results are presented in the Table 2. 
Table 2. The summary of Seabeam 1050D MBES Calibration Parameters.

\begin{tabular}{lc}
\hline System Components & Calibration Parameters \\
\hline Roll (Port Head) & $0.88^{\circ}$ \\
Roll (Starboard Head) & $0.37^{\circ}$ \\
Pitch (Port Head) & $6.89^{\circ}$ \\
Pitch (Starboard Head) & $6.89^{\circ}$ \\
Heading (Port Head) & $0.0^{\circ}$ \\
Heading (Starboard Head) & $0.0^{\circ}$ \\
Navigation Delay (Latency) & $0.03 \mathrm{~s}$ \\
\hline
\end{tabular}

\subsection{Acquisition and Data Processing}

Multibeam acquisition requires several sensors that transfer each data to the Hydrostar software. There were seven input data to Hydrostar; (i) position and speed of the vessel from the F180 Coda Octopus (real time input), (ii) vessel motion data (pith, roll, heave, yaw) from the F180 Coda Octopus (real time input), (iii) headings and course data from F180 Coda Octopus (real time input), (iv) Sound Velocity Surface data from SV real time (real time input), (v) Sound Velocity Profile data from CTD Seabird SBE 9plus data (manual input as ASCII file with special format and extention - *.sva), (vi) Sensor offset from various sensor to RP (Reference Point), (vii) miss-alignment of transducer which was result of path test. Data (vi) and (vii) were stored in vessel file with special format and extention (*.ship).

MBES (Sonar processing unit and transducer) measures range and bearing only. Depth is calculated afterward in the data collection by accounting for the following data: motion, position, refraction, and heading. The projector generates a pulse of sound, also known as a ping. When the sound reach the target (which could the seabed, an object or a fish in the water column), it reflects back toward the receiver. The returning sound is received in multiple beam, 126 beam in the case of Seabeam 1050D.

One beam refers to the sounding depth on the seabed afterward calculate the range and bearing with the following data: motion, position, refraction, and heading. The combination of several pings will produce a set of sounding depth point (commonly is called point cloud) which can be visualized in 2D or 3D to produce seabed topography. The result of the hydrostar acquisition software still have noise and outlier data.

The data need to be edited and filtered using multibeam data processing software. The data was recorded by hydrostar software which can be saved in (*.dat), (*.XSE), and (*.UNB) format. CARIS HIPS 6 and HDP 4061 were used to process the multibeam data in RV Baruna Jaya IV. While the (*.XSE) and (*.UNB) processed by CARIS HIPS 6 software, the (*.dat) one need to processed using HDP 4061 (HDPedit and HDPpost) software.

The acquisition and processing MBES data which are onboard in RV Baruna Jaya IV consist of:

i. Hypack $6.2 b$

Hypack software can be used to make line survey planning and guide the vessel drivers to follow the line survey. When Hypack is logging status which will display navigation data such as position, heading, bearing, distance traveled, remaining distance, and vessel deviation from the survey line. In addition to guide navigation that software can also record data (position, depth, heading, speed, time, etc) from various sensors. 
ii. Hydrostar 3.5.3

Hydrostar software provides all sonar control functions, records bathymetric data and includes various real-time data displays for quality control.

iii. Multibeam processing Software HDP 4061

HDP 4061 software includes HDPedit and HDPpost. This software can only run in the linux operating sytem which need to run in open Suse 10 distro. HDPedit is used to filter the outlier data. HDPpost is used to process data involving vessel file, sound velocity profile, geodetic parameter, and projection. HDPpost can be used to produce gridding, contour map, DTM, and 3D from seabed topography. In this study HDPpost is only used to generate ASCII format (position and depth).

iv. Fledermous 6

Fledermous software is used to make 3D visualization of seabed topography from ASCII format which contain the position and depth data.

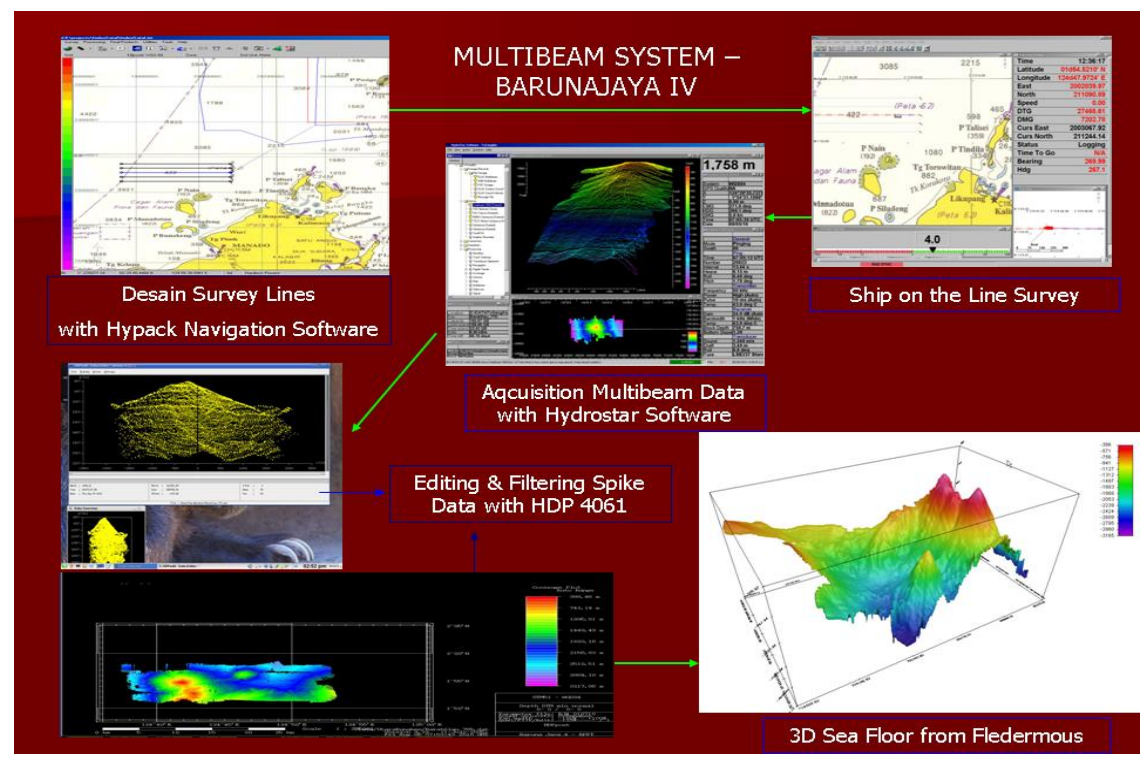

Figure 4. The acquisition and processing multibeam data workflow at RV. Baruna Jaya IV.

\section{RESULTS AND DISCUSSION}

The whole seabed topography in Sangihe Talaud water were presented in geographical coordinate system and using ellipsoid WGS 1984 (Figure 4). It was due to the differences of zone; $52 \mathrm{~N}$ for the north of Talaud Island and $51 \mathrm{~N}$ for the north of Sangihe Island, west of Siau, and north of Nain Island. Seabed topography maps at each location were presented using the UTM projection map. The depth of seabed topography is defined by colors and some geomorphology which can be identified (Figure 5). 


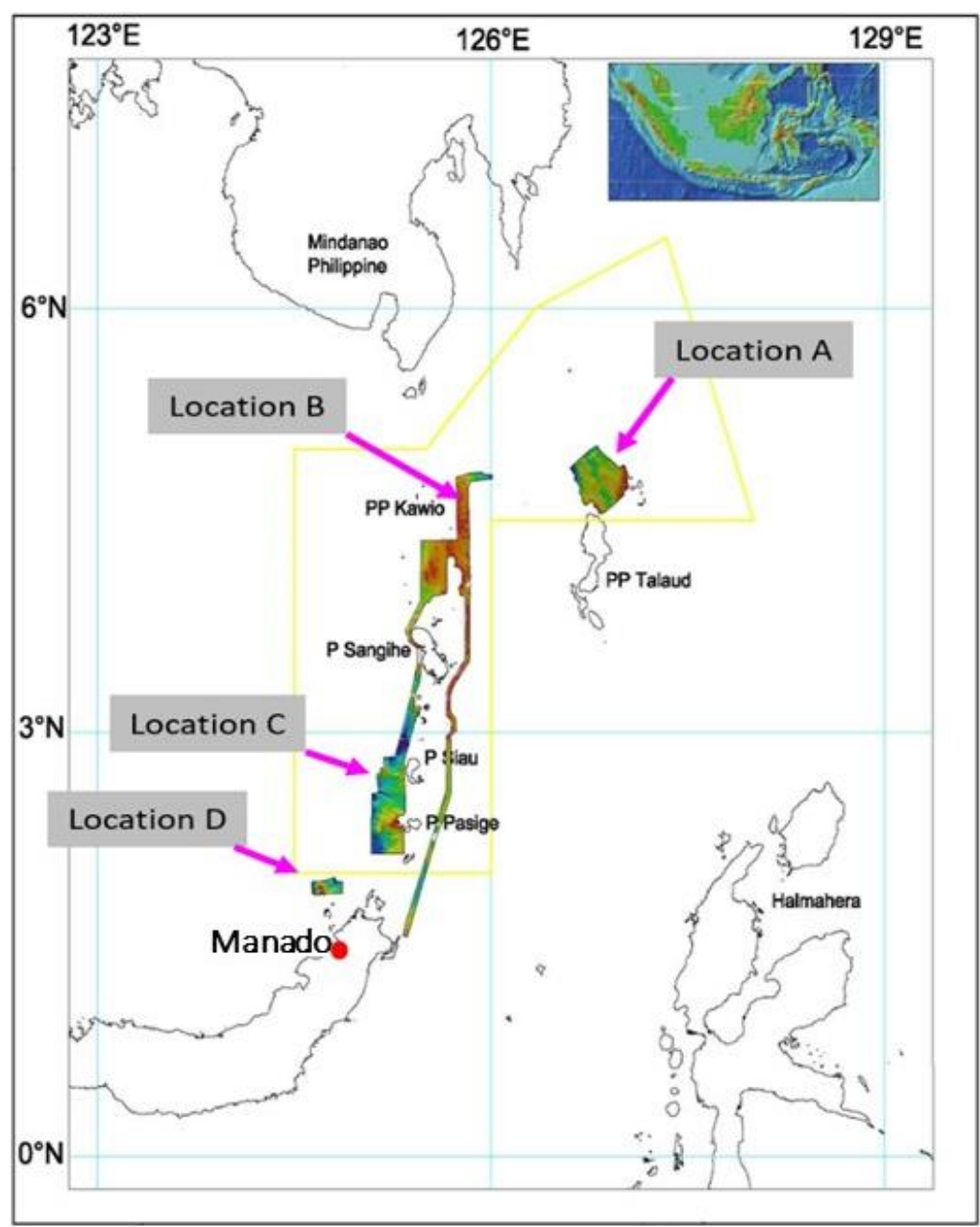

Figure 5. Seabed topography result at study area.

- Location B

Seabed topography at north of Sangihe shows a unique topography. These are shown by many the igneous rock intrusion. These rocks are like hills, which the top of hills is a flat topography. The top of igneous rock intrusion have the range of water depth between $300-500 \mathrm{~m}$. The whole survey area have range of water depth between $34.54-2375.27 \mathrm{~m}$. The deepest area is at northeast, while the shallowest one is at southeast (Figure 6).

- Location C

Seabed topography at location $\mathrm{C}$ shows also a vary topography. There are valley, hill, and seamount. The west side of Ruang Island is found a hill with creek (Figure 7), while seamount is found between Siau Island and Makalehi Island. The hill with creek has a flat area on the top of hill. The top of hill has about $300 \mathrm{~m}$ water depth. The seamount is located at position (E-125'17'3.43"/N-2 $\left.41^{\circ} 39.52^{\prime \prime}\right)$ just about 8 $\mathrm{km}$ to the west from the west coast of Siau Island. According to Menard (1964), seamount are defined as materials originating from the seafloor, forming a slope and height of at least $1 \mathrm{Km}$. The seamount rose up from the depth of $2100 \mathrm{~m}$ to $710 \mathrm{~m}$, or nearly $1400 \mathrm{~m}$ seamount high, and that very steep southern wall of the seamount. The diameter of seamount is between $4000 \mathrm{~m}-5000 \mathrm{~m}$, Figure 8 depicts the base on seabed profile of seamount. The whole survey area have range of water 
depth between $105.6 \mathrm{~m}$ - 3308.2m. The shallowest area is found at near Mahengetang Island, while the deepest area found at northwest of Siau Island.

- Location D

Seabed topography at location D shows a unique topography. There is a conical shape of seamount with lava flow (Figure 9). Schieferdecker (1959) explained that seamounts are defined as an area on the surface of the earth where magma material from the earth comes out or has been out in the past, and will form seamount, and have a crater at the top. This phenomenon can be possible to occur at seamount at location D. The seamount is located at position (E-124'41'50.86"/N-1 $\left.{ }^{\circ} 54^{\prime} 33.67^{\prime \prime}\right)$ just about $14 \mathrm{~km}$ to the northwest from the west coast of Nain Island. The seamount risen up from the depth of $2500 \mathrm{~m}$ to $450 \mathrm{~m}$, or nearly $2000 \mathrm{~m}$ seamount high, and that very steep western wall of the seamount. The diameter of seamount is have range $8000 \mathrm{~m}-10000 \mathrm{~m}$, it can be seen base on seabed profile of seamount (Figure 10). The whole survey area has range of water depth between $385.52 \mathrm{~m}-3165.12 \mathrm{~m}$. The shallowest area is found at the top of seamount, while the deepest area found at westward of seamount.

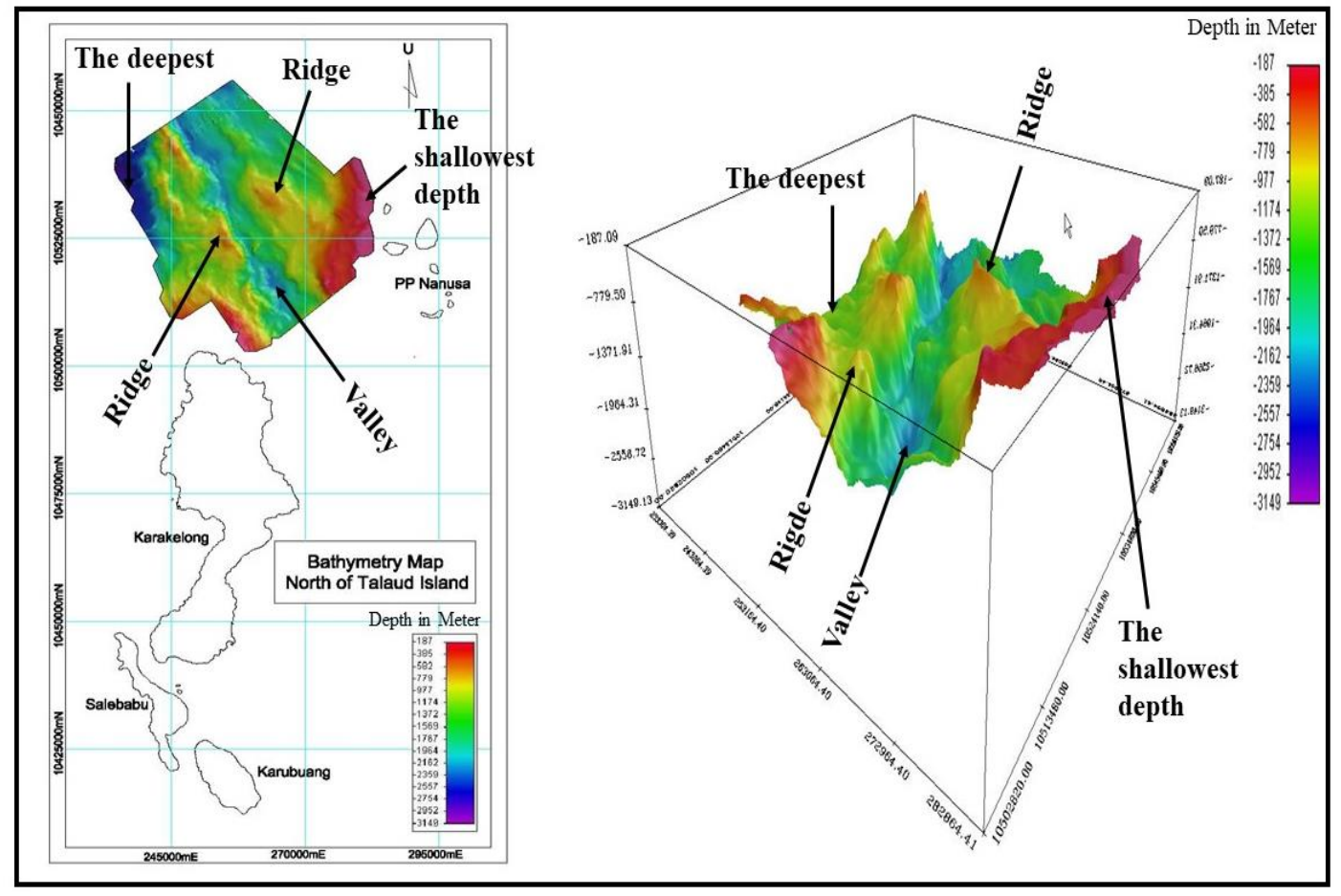

Figure 5. Seabed topography of north Talaud Island. Left picture show $2 \mathrm{D}$ view and right picture show $3 \mathrm{D}$ view. 


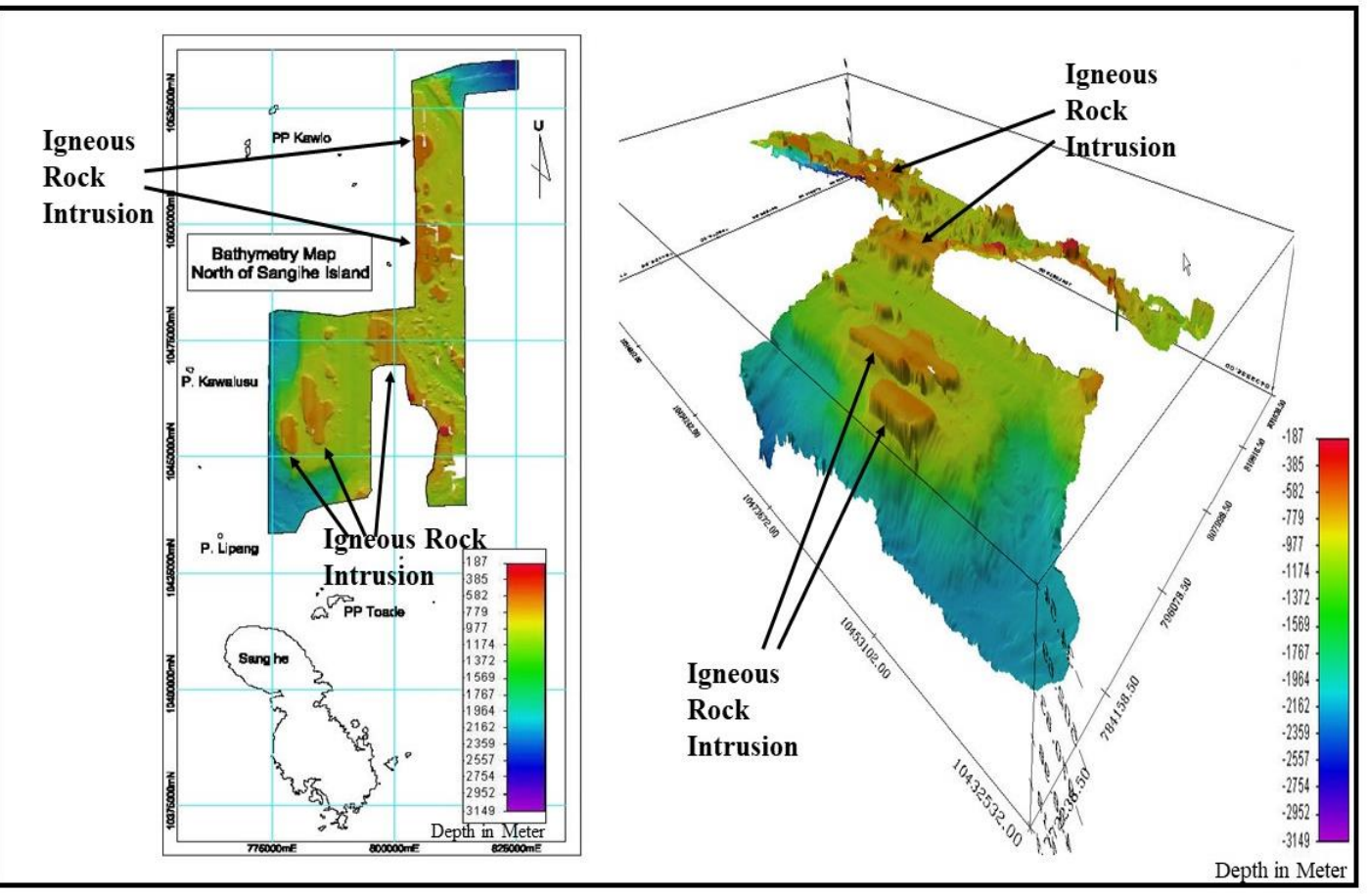

Figure 6. Seabed topography of north Sangihe Island. Left picture show 2D view and right picture show $3 \mathrm{D}$ view.

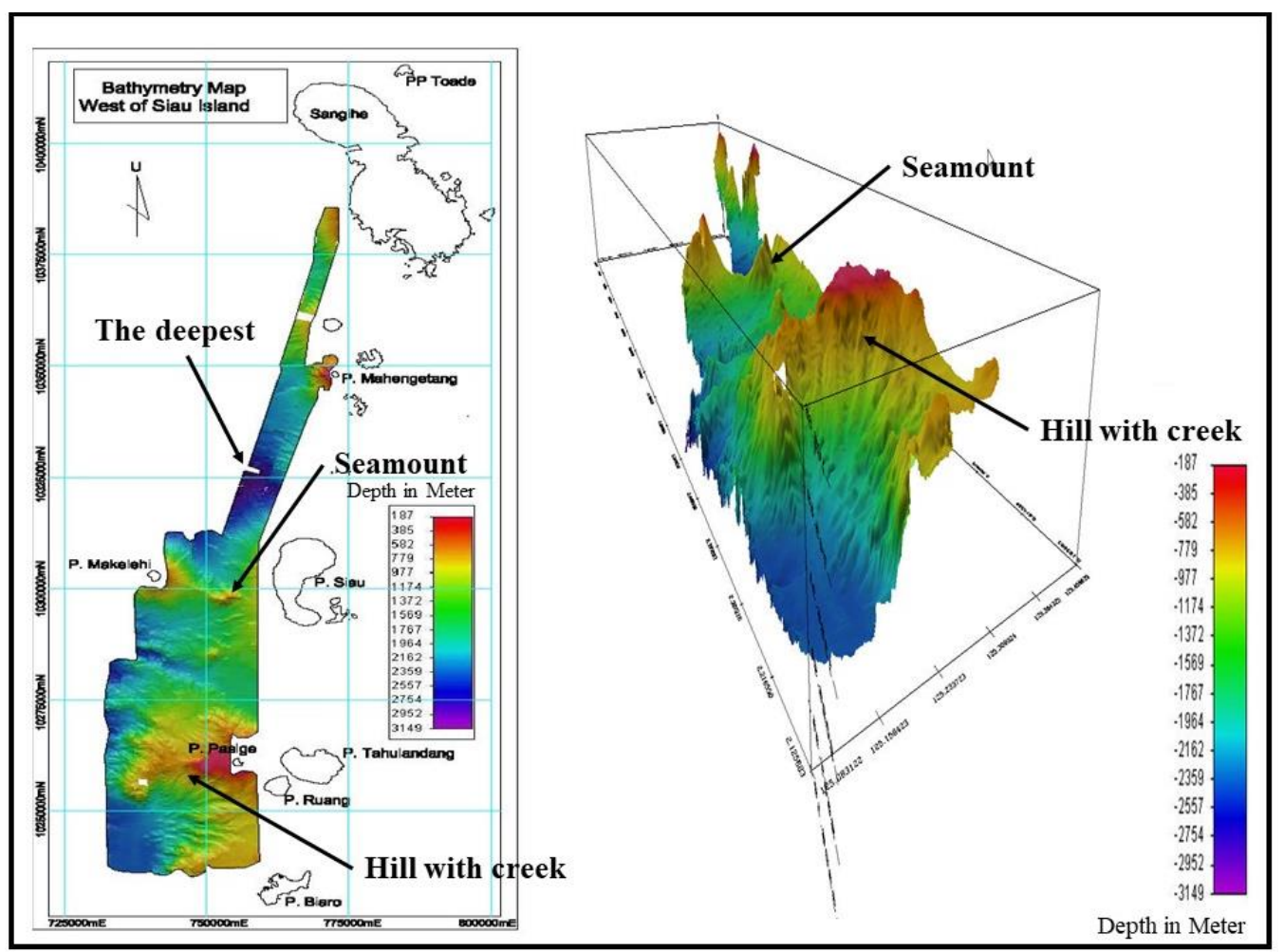

Figure 7. Seabed topography of west Siau Island. Left picture show 2D view and right picture show $3 \mathrm{D}$ view. 


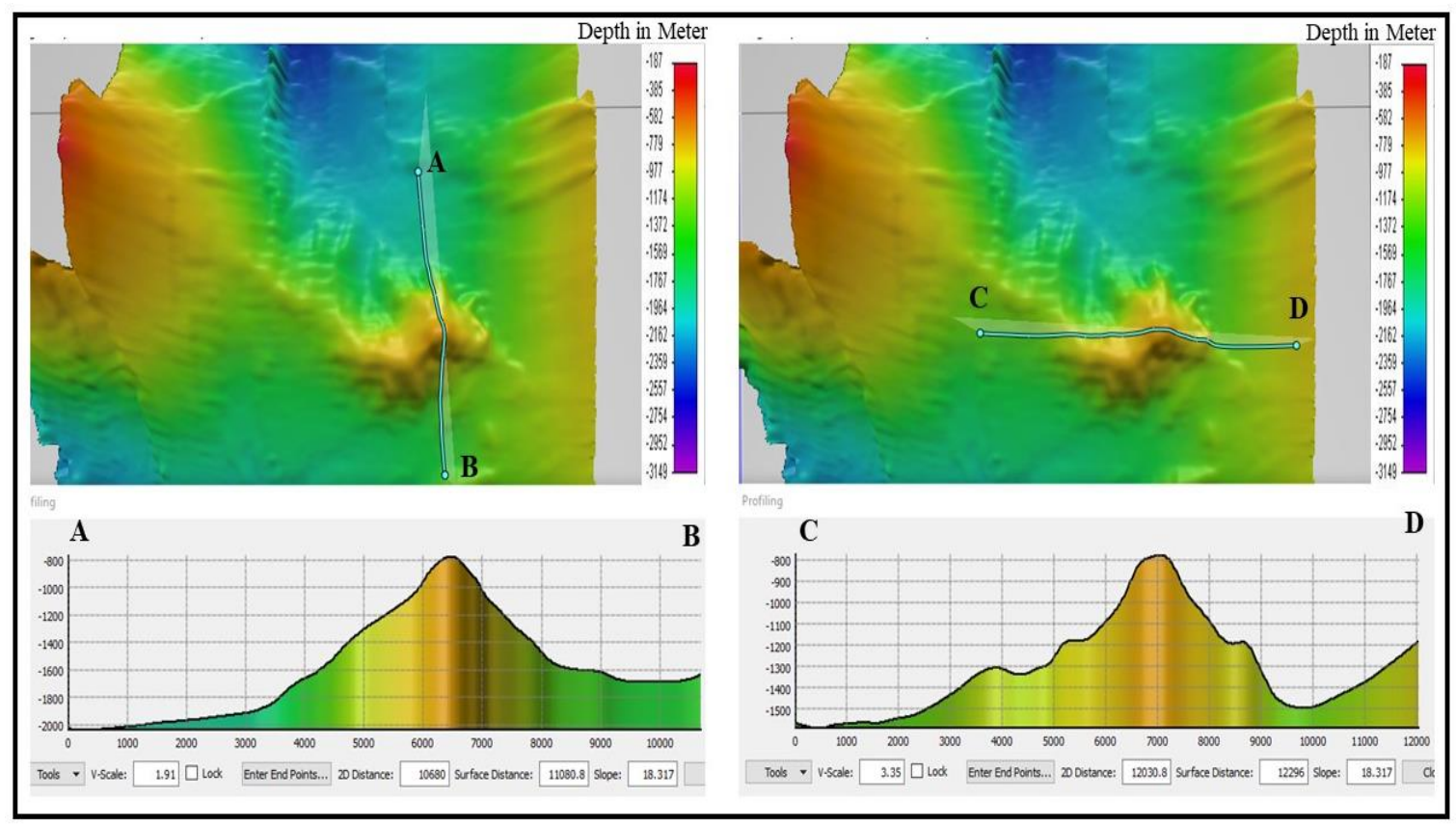

Figure 8. Seabed profile of seamount. Left picture show seabed profile from north to south and right picture show seabed profile from west to east.

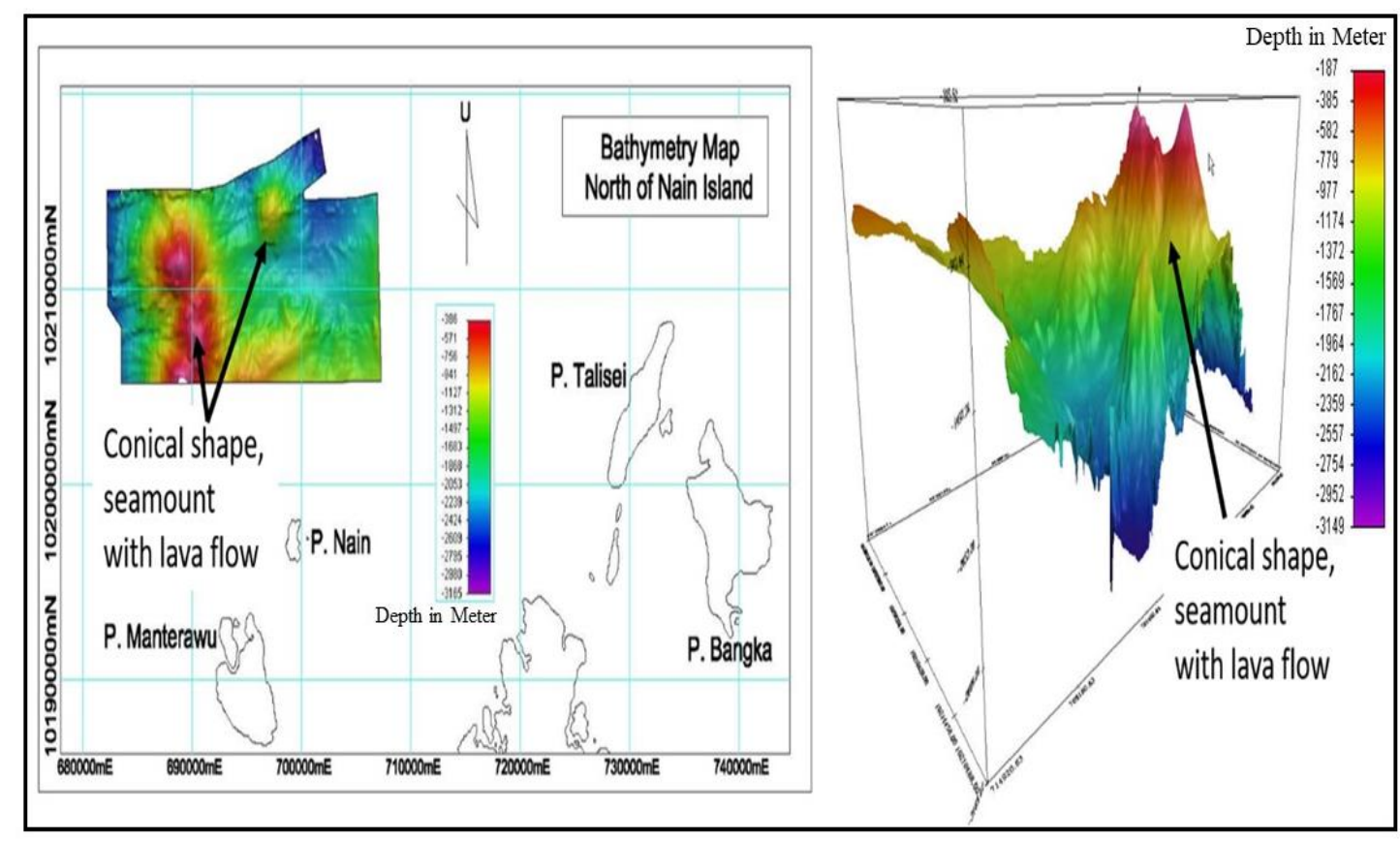

Figure 9. Seabed topography of north Nain Island. Left picture show 2D views and right picture show $3 \mathrm{D}$ view. 


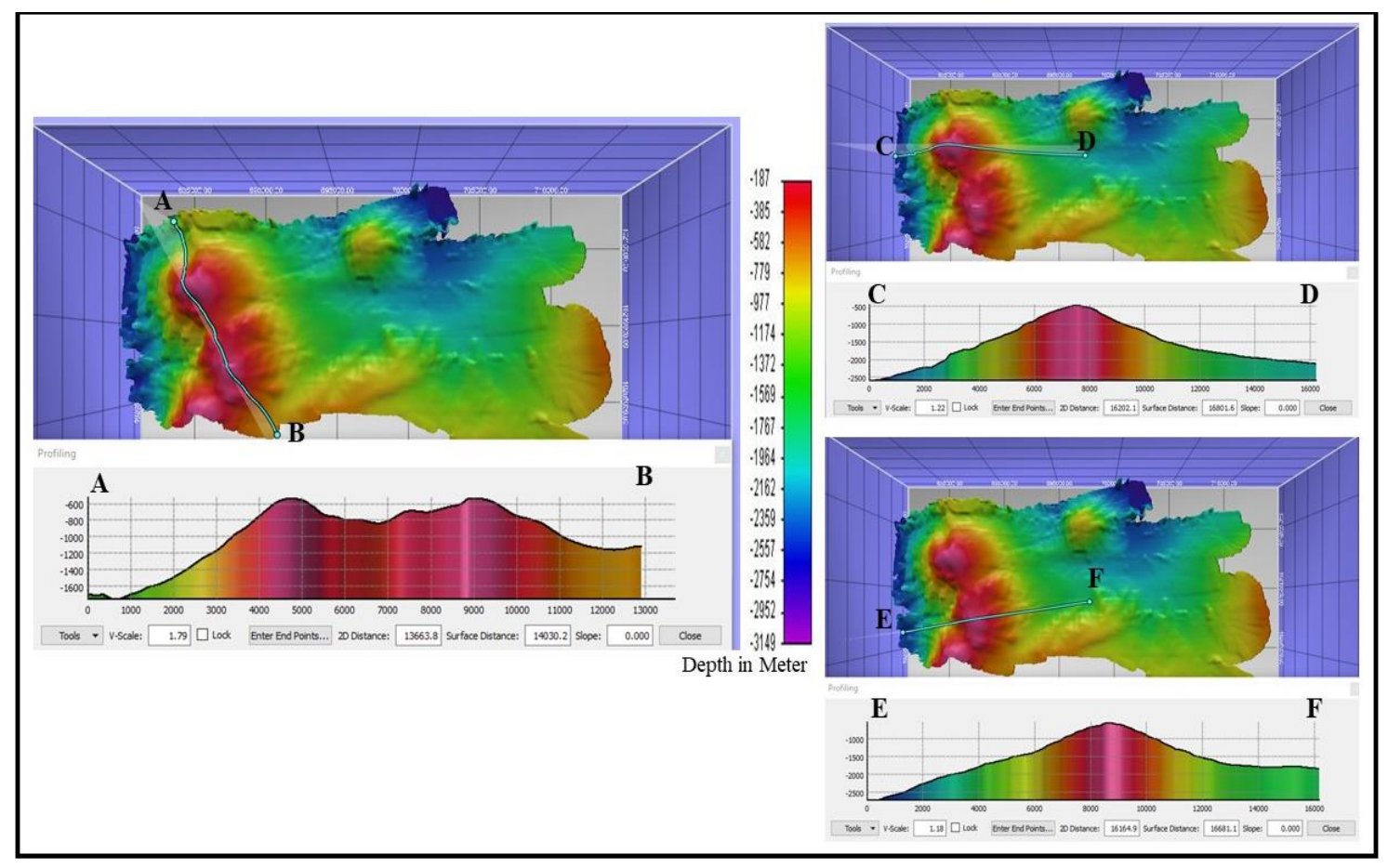

Figure 10. Seabed profile of seamount. Left picture show seabed profile from northwest to southeast, top right picture show seabed profile of first seamount from west to east, and lower right picture show seabed profile of second one from west to east.

\section{CONCLUSION}

The seabed topography in Sangihe Talaud waters has a varied seabed topography. Geomorphology features that found from the multibeam echosounder image are valley, hill with creek, igneous rock intrusion, and seamount. The first seamount is located at position (E-125 $\left.5^{\circ} 17^{\prime} 3.43^{\prime \prime} / \mathrm{N}-2^{\circ} 41^{\prime} 39.52^{\prime \prime}\right)$ just about $8 \mathrm{~km}$ to the west from the west coast of Siau Island. The seamount risen up from the depth of $2100 \mathrm{~m}$ to $710 \mathrm{~m}$, or nearly $1400 \mathrm{~m}$ seamount high, and that very steep southern wall of the seamount. The diameter of seamount is about between $4000 \mathrm{~m}-5000 \mathrm{~m}$. The second one is located at position (E$\left.124^{\circ} 41^{\prime} 50.86^{\prime \prime} / \mathrm{N}-1^{\circ} 54^{\prime} 33.67^{\prime \prime}\right)$ just about $14 \mathrm{~km}$ to the northwest from the west coast of Nain Island. The seamount rose up from the depth of $2500 \mathrm{~m}$ to $450 \mathrm{~m}$ below the sea surface, or nearly $2000 \mathrm{~m}$ of high, and can be categorized as a steep western wall of the seamount. The diameter of seamount is between $8000 \mathrm{~m}-10000 \mathrm{~m}$.

Seabed topography at the north of Sangihe shows a unique topography. There are shown many the igneous rock intrusion. The other unique one is located the Westside of Ruang Island which there is found hill with creek. The hill with creek has the flat area on the top of hill. The top of hill has about $300 \mathrm{~m}$ of water depth. While in northward of Talaud is found a steep and long valley there is among dual ridge.

The seabed topography mapping using multibeam echosounder can offer highresolution map. The method can be used to produce a bathymetry map. Four bathymetry maps have been produced in this study. All maps can be used to geological study, marine habitats, and environmental base line assessment. 


\section{ACKNOWLEDGEMENT}

The author and colleagues would like to thank the Laboratory for Marine Survey Technology, the Agency for the Assessment and Application of Technology (BPPT) for joint in INDEX SATAL expedition and also for the permission granted to use the activity data and reports for publication in this paper.

\section{REFERENCES}

L-3 Communications ELAC Nautik GmbH. (2013). Shallow and Medium Water Multibeam SEA BEAM 1000. Neufeldtstrasse, 24118 Kiel, Germany

Menard, H.W. (1964). Marine geology of the Pacific. New York, McGraw Hill. 271p.

Schieferdecker, A.A.G. (1959). Geological nomenclature. Royal geology and minings Society of the Netherlands. J. Noorduijn en Zoon NV, Gorinchem. 523p.

Wirasantosa, S., Hammond, S.R., Pandoe, W.W, Holden, J.F., Djamaluddin, R., Permana, H., Nganro, N., Abidin, H., Shank, T. M., Priadi, B., Fryer, P., Makarim, S., Sulistiyo, B., Triarso, E., Troa, R., Iswinardi, I., Potter, J., Anantasena, Y., Triyono, T., Surachman, Y.(2010). INDEX SATAL Expedition 2010, a discovery of deep sea potentials. American Geophysical Union, Fall Meeting 2010, abstract id. OS11D-02, San Francisco, December 2010. 